\title{
Revisiting the Tianjiayuanzi section - the stratotype section of the Ediacaran Doushantuo Formation, Yangtze Gorges, South China
}

\author{
MIAO LU, MAOYAN ZHU \& FANGCHEN ZHAO
}

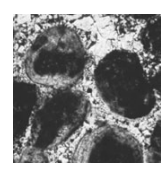

\begin{abstract}
The Ediacaran Doushantuo Formation (dating from $635 \mathrm{Ma}$ to $551 \mathrm{Ma}$ ) of South China is composed of alternating siliciclastic and carbonate units and yields abundant extraordinarily preserved animal embryos, macroscopic multicellular algae and Ediacara-type fossils. Thus, it is critical for the chronostratigraphic calibration of the Ediacaran Period and for deciphering the evolutionary history of life during this time interval. In order to establish a high-resolution Ediacaran chronostratigraphic framework and to clarify the correlation problem of the Doushantuo Formation, we reinvestigated the Tianjiayuanzi section, which is the stratotype section of the Doushantuo Formation. The new carbon isotope and sequence stratigraphic data, as well as the integrative correlation of the Tianjiayuanzi section with other sections in the Yangtze Gorges area demonstrate that there are four negative carbon isotope excursions (N1-N4) in the Doushantuo Formation in the Yangtze Gorges area. The N1 (CANCE) excursion occurs within the cap carbonate interval at the base of the formation. Extreme negative $\delta^{13} \mathrm{C}$ values $(<-18 \%$ ) are recorded within this interval from most of the sections in the Yangtze Gorges area. The N2 (WANCE) excursion, with $\delta^{13} \mathrm{C}$ values shifting from $+6 \%$ o to $-1 \%$, occurs in the middle of Member 2 at a major sequence boundary in the middle of the formation. The N3 excursion is situated in a horizon near the boundary between Member 2 and Member 3 of the formation and is characterized by $\delta^{13} \mathrm{C}$ values down to $-6 \%$. The $\mathrm{N} 4$ (DOUNCE) excursion with a nadir of $\delta^{13} \mathrm{C}$ values as low as $-9.6 \%$ at the top of the formation represents the most distinct negative carbon isotope excursion in the Ediacaran. New observations in the field confirm the presence of a sequence boundary at a karstic surface in the upper part of the Doushantuo Formation, which coincides with the beginning of the nadir of $\delta^{13} \mathrm{C}$ values within the DOUNCE. Additional $\delta^{13} \mathrm{C}$ data from the basal Dengying Formation indicates that the DOUNCE interval with the most negative $\delta^{13} \mathrm{C}$ values crosses entirely the black shale Member 4 at the top of the Doushantuo Formation. - Keywords: Ediacaran, Doushantuo, chemostratigraphy, carbon isotopes, South China.
\end{abstract}

LU, M., ZHU, M.Y. \& ZHAO, F.C. 2012. Revisiting the Tianjiayuanzi section - the stratotype section of the Ediacaran Doushantuo Formation, Yangtze Gorges, South China. Bulletin of Geosciences 87(1), 183-194 (5 figures, 1 table). Czech Geological Survey, Prague. ISSN 1214-1119. Manuscript received September 12, 2010; accepted in revised form October 7, 2011; published online February 29, 2012; issued February 29, 2012.

Miao Lu, Maoyan Zhu (corresponding author) \& Fangchen Zhao, State Key Laboratory of Palaeobiology and Stratigraphy, Nanjing Institute of Geology and Palaeontology, Chinese Academy of Sciences, Nanjing, 210008, China; myzhu@nigpas.ac.cn • Miao Lu, Graduate University of Chinese Academy of Sciences, Beijing, 100049, China

The Ediacaran Period, spanning ca 93 Myr (635-542 Ma), represents a critical transitional time interval in Earth history between the termination of the global Neoproterozoic ice ages and the Cambrian when the Earth experienced revolutionary changes in its biosphere, lithosphere, atmosphere and hydrosphere (Knoll et al. 2004, Squire et al. 2006, Bowring et al. 2007, Canfield et al. 2008). However, due to the absence of a high-resolution Ediacaran time frame, controversies are common with regard to the interpretation of the evolutionary processes of the Earth-Life system during this period (Halverson et al. 2005, Fike et al. 2006, Gaidos et al. 2007, Zhu et al. 2007a, McFadden et al. 2008). Recent advances in Ediacaran chronostratigraphy demonstrate that it is possible to use some geochemical proxies and fossils to subdivide and correlate Ediacaran strata on a global scale (Grey 2005, Zhu et al. 2007b, McFadden et al. 2009, Halverson et al. 2010). Ediacaran strata of South China are fossiliferous and composed of alternating siliciclastic and carbonate lithologies, making them among the best successions in the world for the calibration of Ediacaran time (Zhu et al. 2007b). The Doushantuo Formation, in particular, yields abundant, extraordinarily well preserved animal embryos, macroscopic multicellular algae and Ediacara-type fossils (Xiao et al. 1998, 2004; Chen et al. 2002, 2009; Yin et al. 2007; Zhu et al. 2008) that have attracted worldwide attention 


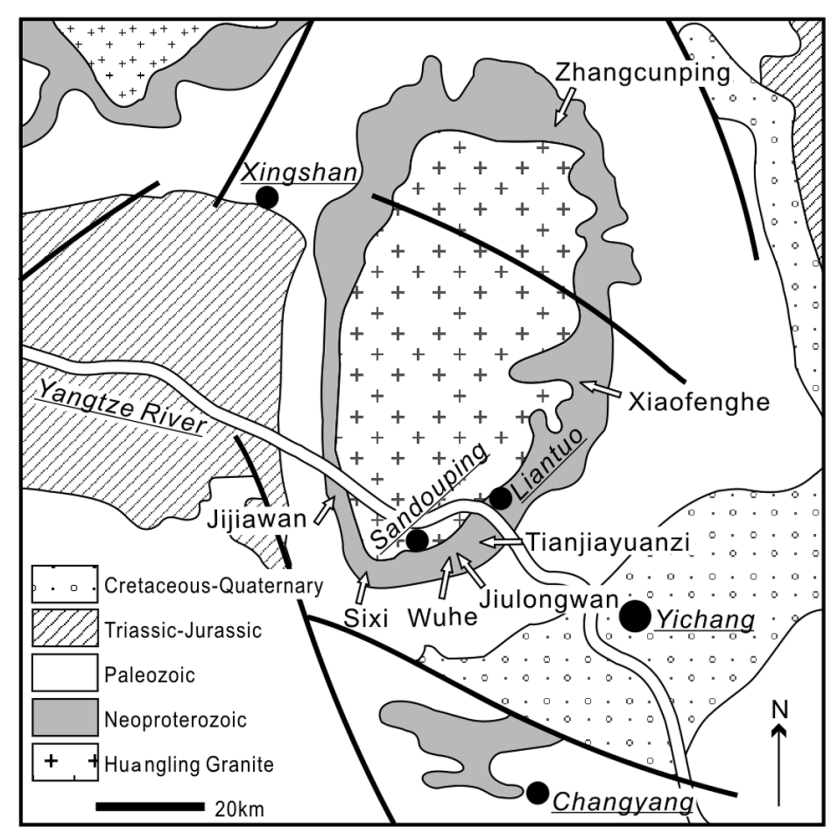

Figure 1. Geological map of the Huangling Anticline in western Hubei showing locations of the sections of the Doushantuo Formation.

(Jiang et al. 2003a, 2007; Zhu et al. 2007b; McFadden et al. 2008; Bristow et al. 2009; Li et al. 2010).

The Doushantuo Formation is well dated at the base (635 Ma) and at the top (551 Ma) (Condon et al. 2005) and represents more than $90 \%$ of Ediacaran Period. Therefore, high-resolution stratigraphy of the Doushantuo Formation is urgently required for global Ediacaran chronostratigraphy. As the type area of the Ediacaran System of South China, the Yangtze Gorges area of western Hubei has the best developed and exposed sections of the Doushantuo Formation. Over the past two decades, most previous stratigraphic work on the Doushantuo Formation has been focused on carbon isotope evolution (Lambert $e t$ al. 1987; Wang et al. 1996, 2002a, b; Yang et al. 1999; Chen et al. 2003; Chu et al. 2003; Jiang et al. 2007; Zhu et al. 2007b; Lu et al. 2009; Sawaki et al. 2010). However, the carbon isotope profile of the Doushantuo Formation exhibits significant variations between different sections in the area. Therefore, there is currently no consensus with regard to the precise stratigraphic correlation of the Doushantuo Formation, not only in different areas of South China but also in the Yangtze Gorges area (Zhou \& Xiao 2007, Zhu et al. 2007b, McFadden et al. 2009). This corre- lation problem is mainly due to variations in sedimentary facies, which lead to dramatic differences in the lithology and thickness of the Doushantuo Formation in different sections in the Yangtze Gorges area (Zhu et al. 2007b, Lu et al. 2009).

In order to obtain a high-resolution stratigraphy of the Doushantuo Formation, we revisited the Tianjiayuanzi section in 2008 and 2010 for two reasons: 1) the section is the stratotype section of the Doushantuo Formation (Zhao et al. 1985), but there is still no high-resolution $\delta^{13} \mathrm{C}$ profile available from the section (Chu et al. 2003); and 2) the prominent $\delta^{13} \mathrm{C}$ excursion in the uppermost Doushantuo Formation, abbreviated to DOUNCE by Zhu et al. (2007a), is puzzlingly inconspicuous in this section as shown by previous studies (Chu et al. 2003). The purpose of the present paper is to report new information about $\delta^{13} \mathrm{C}$ - and sequence-stratigraphy of the section, and its applicability for correlation of the Doushantuo Formation in the Yangtze Gorges area.

\section{Description of the Tianjiayuanzi section}

The Tianjiayuanzi section is located at the southeastern limb of the Huangling Anticline in the vicinity of Sandouping, Yichang (Fig. 1). The section is exposed along a farm trail on the southern hillside of the Tianjiayuanzi village, starting at $30^{\circ} 49.964^{\prime} \mathrm{N} / 111^{\circ} 06.587^{\prime} \mathrm{E}$ and ending at $30^{\circ} 49.861^{\prime} \mathrm{N} / 111^{\circ} 06.470^{\prime} \mathrm{E}$. In this section, the Doushantuo Formation is about $200 \mathrm{~m}$ thick (Fig. 2A). Since the middle part of the section is not well exposed, only the lower and upper parts were measured and sampled in the present study.

The Doushantuo Formation in this section starts with a 2.8 m-thick cap carbonate interval, consisting predominantly of microcrystalline dolostone and situated directly above the Nantuo glacial diamictite (Fig. 2B). The basal $0.8 \mathrm{~m}$ of the cap carbonate is strongly disrupted by stromatactis-like cavities and siliceous crusts. Above this basal layer follows a $1.2 \mathrm{~m}$-thick, gray, thickly bedded, laminated and microcrystalline dolostone with tepee-like structures. The top part of the cap carbonate is composed of a $0.8 \mathrm{~m}$-thick, gray, medium- to thick-bedded dolostone with centimeter-scale stromatactis-like cavities and sheet cracks.

Overlying the cap carbonate is a $48.6 \mathrm{~m}$-thick interval consisting of dark gray, muddy dolostone intercalated with

Figure 2. Field photographs of the Doushantuo Formation in the Tianjiayuanzi section. $\bullet$ A - overview of the Tianjiayuanzi section. The Doushantuo Formation is in the lower part of the figure, and the uppermost cliff is made up of the Dengying Formation. • B - cap carbonate at the base of the Doushantuo Formation. $\bullet \mathrm{C}$ - lower part of Member 2, showing carbonate in the upper part of the sequence $1 . \bullet \mathrm{D}-$ carbonate interval of the lower part of Member 3, note the contorted thick bed at its base. $\bullet$ E - upper part of Member 3, showing massive oolitic dolostone in the lower part and laminated carbonate in the upper part. $\bullet \mathrm{F}$ - laminated carbonate with $\delta^{13} \mathrm{C}$ values of $-9 \%$ at the top of Member 3 . $\bullet \mathrm{G}-$ contact between black shale at the top of the Doushantuo Formation and carbonate at the base of the Dengying Formation. 

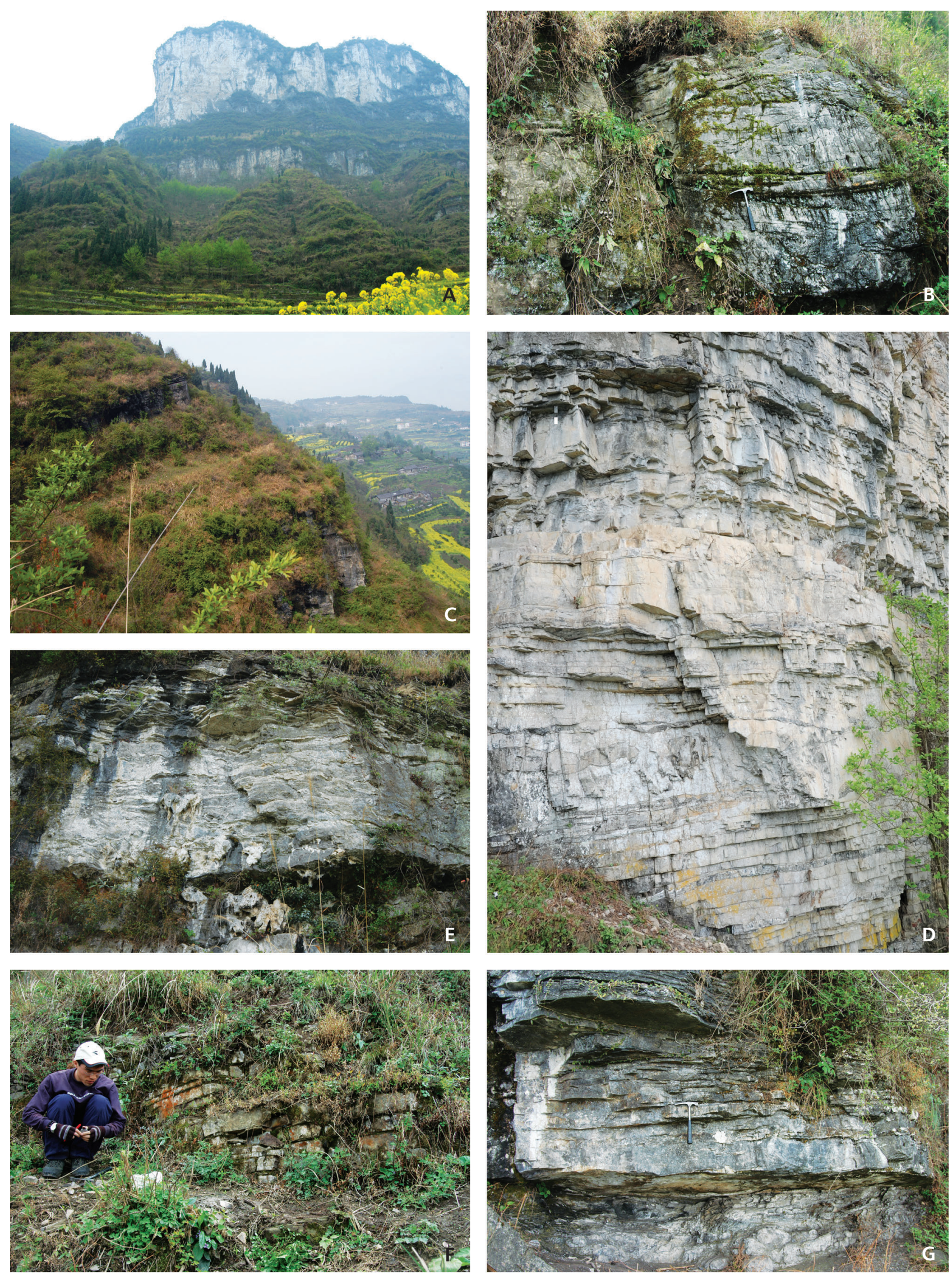

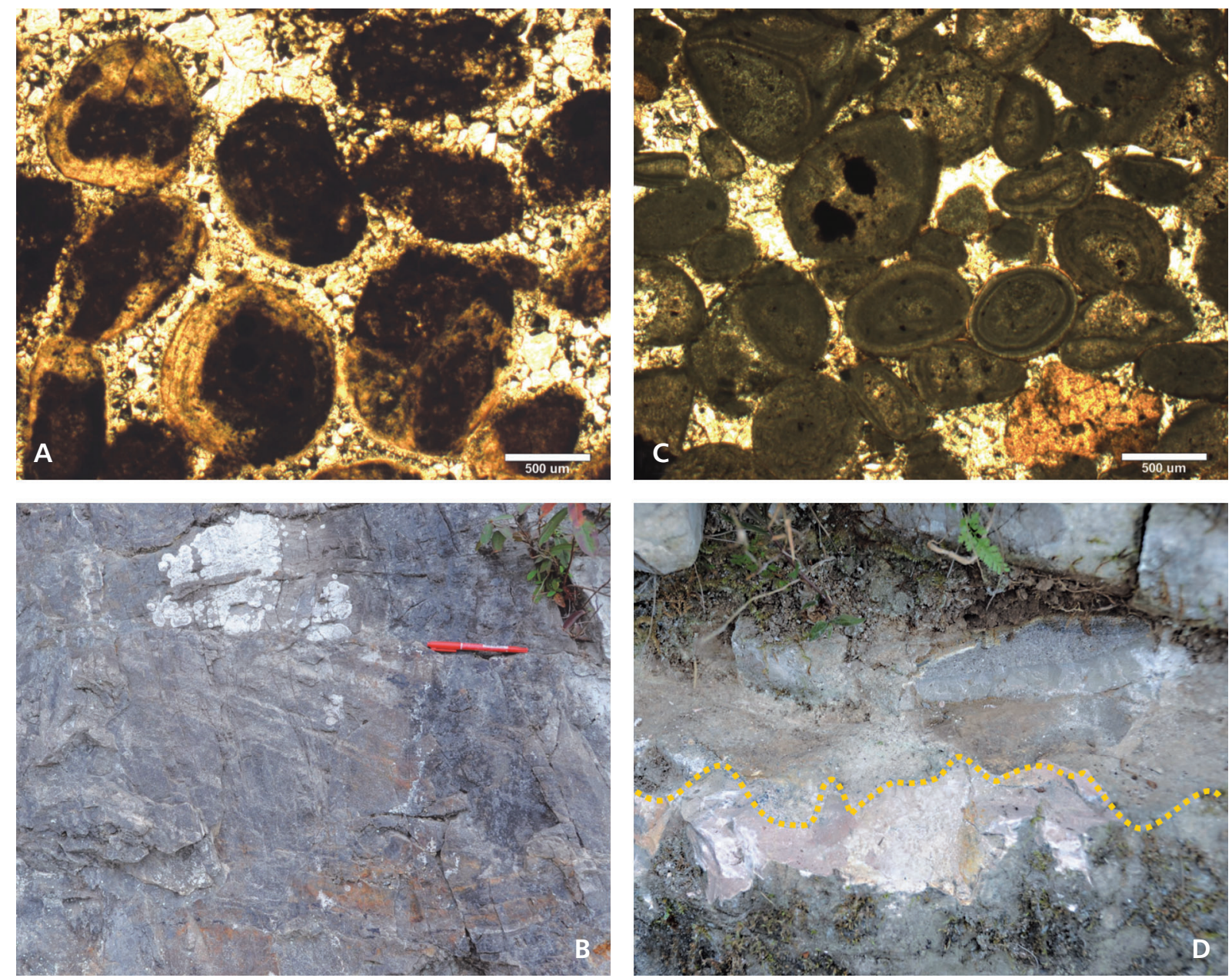

Figure 3. Field and thin section photographs of the oolitic carbonate in the upper part of Member 3 of the Doushantuo Formation in the Tianjiayuanzi section. $\bullet \mathrm{A}$ - thin section photographs of well preserved ooids of the oolitic dolostone from the horizon shown by B. $\bullet$ B - massive oolitic dolostone with large cross-stratifications. $\bullet \mathrm{C}$ - thin section photographs of well preserved ooids of the oolitic dolostone from the horizon shown by $\mathrm{D}$. $\bullet \mathrm{D}-$ erosional surface with irregular karstic infilling of ooids at the top of Member 3.

black shales in its lower part, and muddy/silty dolostone intercalated with medium-bedded, laminated microcrystalline dolostone and oolitic dolostone in its upper part (Fig. 2C). Small black cherty nodules are intermittently present from the lower to the upper part of this interval. Above the lower Doushantuo Formation, thin-bedded silty dolostone intercalated with black shales widely occur. Unfortunately, this interval is not very well exposed and detailed measurements therefore were not made in the present study.

The upper part of the Doushantuo Formation in this section is a carbonate interval consisting of two parts in ascending order: 1) the lower $46 \mathrm{~m}$ is of light gray, mediumto thick-bedded microcrystalline dolostone with abundant black cherty interlayers or lenticular beds and irregular cherty nodules (Fig. 2D), including a 0.9 m-thick, contorted bed near the base and two thin beds of dolomitic grainstone at $23 \mathrm{~m}$ and $28 \mathrm{~m}$, measured from the base of this interval; and 2) the upper part (Fig. 2E) is composed of a lower $6.2 \mathrm{~m}$-thick, gray, massive oolitic dolostone interbedded with light gray microcrystalline dolostone (Fig. 3A, B) with an irregular karstic infilling of oolites $(5-20 \mathrm{~cm})$ at the top (Fig. 3C, D); and an upper $2.5 \mathrm{~m}$-thick, gray, medium-bedded microcrystalline dolostone which is not very well exposed (Fig. 2F).

The topmost part of the Doushantuo Formation of the section is marked by a $\mathrm{ca} 15 \mathrm{~m}$-thick carbonaceous shale member with lenticular carbonate layers and concretions, which is then overlain by medium-bedded dolostone of the Hamajing Member of the Dengying Formation (Fig. 2G).

Figure 4. Stratigraphic log of the Tianjiayuanzi section with carbon isotope profile. 
Miao Lu et al. - Stratotype section of the Ediacaran Doushantuo Formation in South China

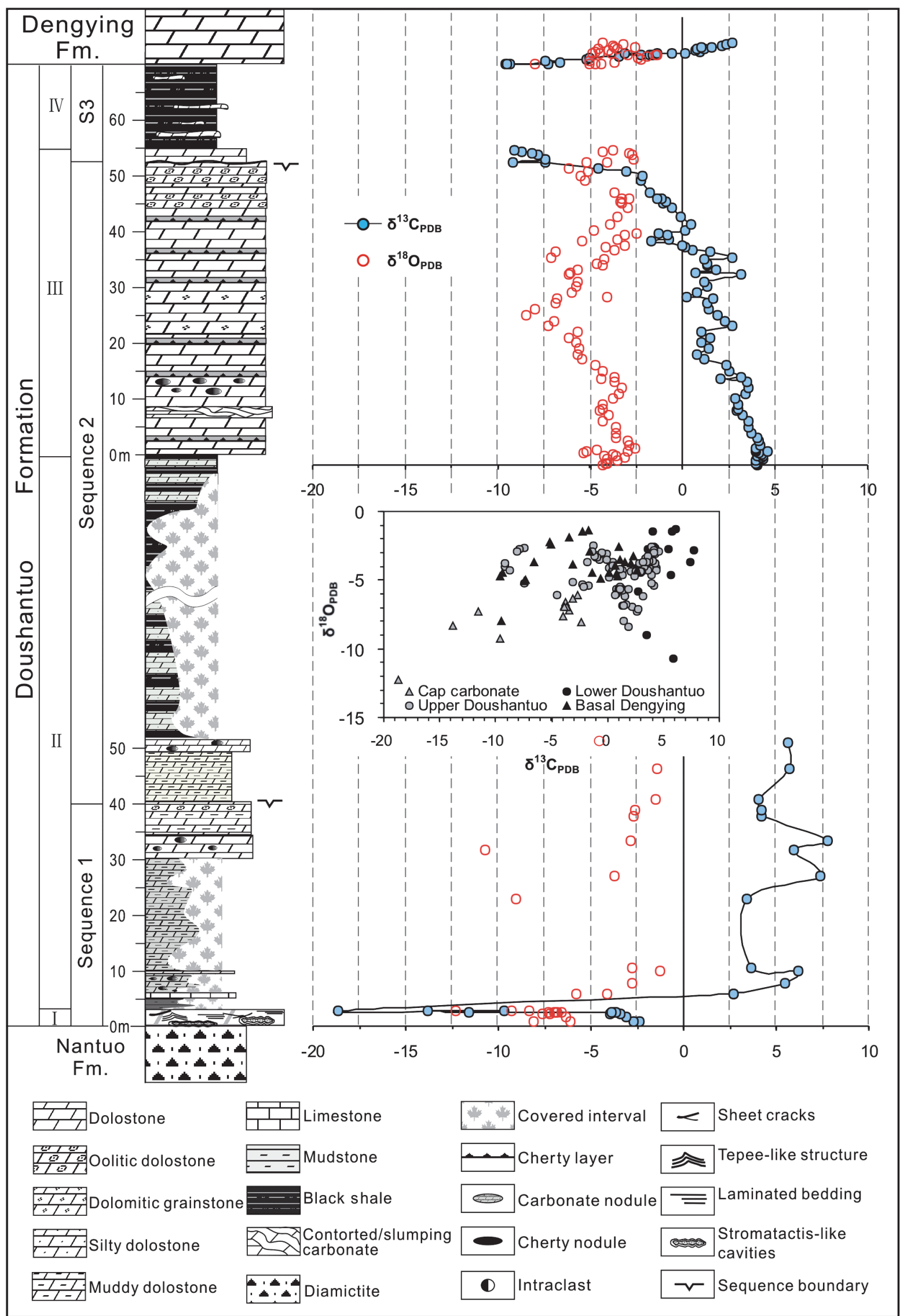




\section{$\mathrm{C}$ and $\mathrm{O}$ isotope analysis and results}

Carbonate samples for the carbon isotope analysis were collected with a stratigraphic spacing of approximately $1 \mathrm{~m}$ in the lower and upper Doushantuo Formation in the section. A higher sample resolution of $c a 0.1 \mathrm{~m}$ spacing was preformed at certain critical stratigraphic intervals such as the cap carbonate. The middle part of Doushantuo Formation was not systematically sampled owing to poor exposure in the Tianjiayuanzi section. A total of 136 dolostone samples bearing no signs of significant diagenetic alteration were analyzed. In general, a thin uniform slice was chosen from the fragments of each sample and then pulverized into a fine powder. $20 \mu \mathrm{g}$ of powder from each sample were reacted with orthophosphoric acid at $50{ }^{\circ} \mathrm{C}$ for more than 24 hours in order to produce the $\mathrm{CO}_{2}$ in the laboratory of the Nanjing Institute of Geology and Palaeontology, Chinese Academy of Sciences. $\delta^{13} \mathrm{C}$ and $\delta^{18} \mathrm{O}$ compositions of the liberated $\mathrm{CO}_{2}$ were measured with a Finnigan MAT-252 mass spectrometer in the State Key Laboratory for Mineral Deposit Research, Nanjing University. Chinese GBW00405 carbonate standards were used for checking memory effects and isotopic calibration $\left(\delta^{13} \mathrm{C}_{\mathrm{PDB}}=\right.$ $0.57 \pm 0.03 \%$ \% $\delta^{18} \mathrm{O}_{\mathrm{PDB}}=-8.49 \pm 0.13 \%$ o) .

Diagenetic alternation of the isotope values were tested through some well-established geochemical criteria. For example, carbonate rocks with $\delta^{18} \mathrm{O}<-10 \%$ are often thought of as having been affected by diagenesis, while positive correlation between $\delta^{13} \mathrm{C}$ and $\delta^{18} \mathrm{O}$ is generally regarded as a sign of altered $\delta^{13} \mathrm{C}$ compositions (Derry et al. 1992, Kaufman \& Knoll 1995). The linear relationship between $\delta^{13} \mathrm{C}$ and $\delta^{18} \mathrm{O}$ values of the cap carbonate samples $\left(\mathrm{R}^{2}=0.672\right)$ indicates substantial diagenetic alteration of the majority of cap carbonate samples, possibly resulting from dolomitization. However, the data from the remaining samples in the section do not show obvious co-variation between $\delta^{13} \mathrm{C}$ and $\delta^{18} \mathrm{O}$ values, suggesting that the carbonate samples analyzed were not significantly affected by diagenesis and have retained the primary $\delta^{13} \mathrm{C}$ composition of seawater carbonate (Fig. 4).

$\delta^{18} \mathrm{O}$ values of the Doushantuo Formation in the Tianjiayuanzi section are relatively invariant. In contrast, the $\delta^{13} \mathrm{C}$ values exhibit significant change through the entire Doushantuo Formation of the section (Fig. 4; Table 1). $\delta^{13} \mathrm{C}$ values of the cap dolostone are highly variable ranging from $-2.4 \%$ to $-18.7 \%$. The extremely negative $\delta^{13} \mathrm{C}$ values $(-11.6 \%$ -18.7\%o) are obtained from the $0.2 \mathrm{~m}$-thick microcrystalline dolostone in the topmost part of the cap carbonate. Although high-resolution microcrystalline carbonate samples are unavailable, $\delta^{13} \mathrm{C}$ values in the lower part $(2.8 \sim 51.4 \mathrm{~m})$ of the Doushantuo Formation in the section show a distinct fluctuation between $+2 \%$ to $+7 \%$ o without noticeable excursions. $\delta^{13} \mathrm{C}$ values decrease progressively from $+4.5 \%$ to $0 \%$ across a $\mathrm{ca} 40 \mathrm{~m}$ interval of the lower and middle dolostone interval with cherty interlayers in the upper part of the Doushantuo Formation. The overlying pronounced negative $\delta^{13} \mathrm{C}$ excursion (DOUNCE) spans a ca $32 \mathrm{~m}$-thick interval and exhibits a nadir down to $-9.6 \%$. The DOUNCE can be subdivided into three stages in this section: 1$)$ a decreasing stage from $\delta^{13} \mathrm{C}$ values of around $0 \%$ to $-7.4 \%$ o through the upper dolostone interval with cherty interlayers and oolitic interbeds; 2) a middle stage with $\delta^{13} \mathrm{C}$ values remaining low between $-7.4 \%$ and $-9.6 \%$, ranging from a $2.5 \mathrm{~m}$-thick microcrystalline dolostone to the base of the Dengying Formation and thereby span the $c a 15 \mathrm{~m}$ interval of the carbonaceous shale member of the topmost part of the Doushantuo Formation; and 3) a stage of increasing $\delta^{13} \mathrm{C}$ values from $-9 \%$ up to $+2.6 \%$ over a $3.9 \mathrm{~m}$ interval of massive dolostone at the base of the Dengying Formation.

\section{Discussion}

\section{Sequence stratigraphy of the Doushantuo Formation in the Yangtze Gorges}

The Doushantuo Formation in the Yangtze Gorges area can be subdivided into four members: 1) Member 1 is represented by the cap carbonate at the base; 2) Member 2 is characterized by interbedded black shale and silty dolostone; 3) Member 3 consists of carbonate with chert nodules; and 4) Member 4 (Miaohe Member) is a black shale interval at the top of the formation (Wang et al. 1998). The lithostratigraphic subdivision of the Doushantuo Formation into four members is very useful and has been widely applied to sections in the Yangtze Gorges. However, the subdivision cannot generally be applied to sections outside the Yangtze Gorges, or even in nearby sections in the northern area of the Huangling Anticline (Fig. 1; Zhu et al. 2007b). Since the Doushantuo Formation represents deposition in an epicontinental basin with a very complex seafloor topography inherited from the Nantuo glaciation, it exhibits remarkable variations in thickness, facies and lithology in different parts of the Yangtze Platform (Zhu et al. 2007b, Jiang et al. 2011), therefore, as pointed out by Zhu et al. (2003), the widespread application of a lithostratigraphic subdivision based on the sequence in the Yangtze Gorges should be abandoned. Recent investigations indicate that sequence stratigraphy is a more practical tool for subdivision and correlation of the Doushantuo Formation (Jiang et al. 2003b, Zhu et al. 2007b) because the sequence surfaces are usually bounded by evidence of subaerial exposure, nondeposition, or an abrupt superposition of disparate facies in the field (Van Wagoner et al. 1990).

Based on investigation of a number of sections throughout the entire Yangtze Platform, Zhu et al. (2007b) recognized two major sequence boundaries within the 
Table 1. $\delta^{13} \mathrm{C}$ and $\delta^{18} \mathrm{O}$ data of samples from the Tianjiayuanzi section (Yangtze Gorges), Yichang, Hubei Province.

\begin{tabular}{|c|c|c|c|c|c|c|c|c|c|c|c|}
\hline Sample & Depth (m) & $\delta^{13} \mathrm{C}_{\mathrm{PDB}}$ & $\delta^{18} \mathrm{O}_{\mathrm{PDB}}$ & Sample & Depth (m) & $\delta^{13} \mathrm{C}_{\mathrm{PDB}}$ & $\delta^{18} \mathrm{O}_{\mathrm{PDB}}$ & Sample & Depth (m) & $\delta^{13} \mathrm{C}_{\mathrm{PDB}}$ & $\delta^{18} \mathrm{O}_{\mathrm{PDB}}$ \\
\hline TJA 0.7 & 0.7 & -2.4 & -8.1 & TJI 6.0 & 6.0 & 3.6 & -4.3 & TJC-9.7 & 42.5 & -0.1 & -3.6 \\
\hline TJA 0.9 & 0.9 & -2.7 & -6.1 & TJI 7.0 & 7.0 & 3.2 & -4.0 & TJC-8.0 & 44.2 & -0.6 & -3.0 \\
\hline TJA 1.7 & 1.7 & -3.1 & -6.4 & TJI 7.9 & 7.9 & 2.9 & -4.5 & TJC-7.2 & 45.0 & -1.1 & -3.3 \\
\hline TJA 2.1 & 2.1 & -3.4 & -7.2 & TJI 8.1 & 8.1 & 3.0 & -4.4 & TJC-6.9 & 45.3 & -0.9 & -3.3 \\
\hline TJA 2.3 & 2.3 & -4.0 & -7.6 & TJI 9.0 & 9.0 & 3.0 & -4.3 & TJC-6.5 & 45.7 & -1.2 & -3.3 \\
\hline TJA 2.4 & 2.4 & -3.8 & -6.9 & TJI 10.0 & 10.0 & 2.8 & -3.8 & TJC-6.3 & 45.9 & -1.4 & -2.9 \\
\hline TJA 2.45 & 2.5 & -3.8 & -6.6 & TJI 11.0 & 11.0 & 3.4 & -3.5 & TJC-5.8 & 46.4 & I & I \\
\hline TJA 2.5 & 2.5 & -3.7 & -7.0 & TJI 12.0 & 12.0 & 3.6 & -3.3 & TJC-5.4 & 46.8 & -1.8 & -3.6 \\
\hline TJA 2.55 & 2.6 & -3.9 & -6.9 & TJI 13.0 & 13.0 & 3.5 & -3.7 & TJC-3.0 & 49.1 & -2.3 & -5.3 \\
\hline TJA 2.6 & 2.6 & -11.6 & -7.3 & TJI 13.6 & 13.6 & 2.0 & -4.4 & TJC-2.4 & 49.7 & -2.1 & -5.5 \\
\hline TJA 2.65 & 2.7 & -13.8 & -8.3 & TJI 14.0 & 14.0 & 3.1 & -3.7 & TJC-1.6 & 50.6 & -3.1 & -5.1 \\
\hline TJA 2.7 & 2.7 & -9.7 & -9.3 & TJI 15.0 & 15.0 & 2.5 & -4.4 & TJC-1.0 & 51.2 & -4.5 & -6.1 \\
\hline TJA 2.8 & 2.8 & -18.7 & -12.3 & TJI 16.0 & 16.0 & 2.4 & -4.7 & TJC- -0.01 & 52.2 & -7.4 & -5.2 \\
\hline TJA 5.7 & 5.7 & 2.7 & -4.2 & TJI 17.0 & 17.0 & 1.1 & -5.5 & TJC 0.01 & 52.2 & -9.2 & -4.1 \\
\hline TJA 5.9 & 5.9 & 2.7 & -5.8 & TJI 18.0 & 18.0 & 0.8 & -5.7 & TJC 0.55 & 52.8 & -7.4 & -2.7 \\
\hline TJA 7.8 & 7.8 & 5.5 & -2.8 & TJI 19.0 & 19.0 & 1.4 & -5.6 & TJC 1.5 & 53.7 & -7.8 & -2.7 \\
\hline TJA10.0 & 10.0 & 6.2 & -1.2 & TJI 20.0 & 20.0 & 1.0 & -5.7 & TJC 1.7 & 53.9 & -8.1 & -2.9 \\
\hline TJA 10.6 & 10.6 & 3.6 & -2.8 & TJI 21.0 & 21.0 & 1.5 & -6.2 & TJC 2.0 & 54.2 & -8.7 & -4.3 \\
\hline TJA 23.0 & 23.0 & 3.4 & -9.0 & TJI 22.0 & 22.0 & 1.0 & -5.7 & TJC 2.25 & 54.5 & -9.1 & -3.8 \\
\hline TJA 27.0 & 27.0 & 7.4 & -3.7 & TJI 23.0 & 23.0 & 2.7 & -7.3 & TJD 0.04 & 69.7 & -9.6 & -4.7 \\
\hline TJA 31.9 & 31.9 & 5.9 & -10.7 & TJI 24.0 & 24.0 & 2.2 & -7.0 & TJD 0.07 & 69.8 & -9.3 & -4.4 \\
\hline TJA 33.5 & 33.5 & 7.8 & -2.8 & TJI 25.0 & 25.0 & 1.9 & -8.4 & TJD 0.1 & 69.8 & -7.3 & -5.0 \\
\hline TJA 38.0 & 38.0 & 4.2 & -2.7 & TJI 26.0 & 26.0 & 1.4 & -8.0 & TJD 0.2 & 69.9 & -9.5 & -8.0 \\
\hline TJA 39.0 & 39.0 & 4.2 & -2.6 & TJI 27.0 & 27.0 & 1.4 & -6.8 & TJD 0.4 & 70.1 & -6.6 & -3.7 \\
\hline TJA 41.0 & 41.0 & 4.1 & -1.5 & TJI 28.0 & 28.0 & 1.6 & -6.8 & TJD 0.6 & 70.3 & -7.5 & -5.0 \\
\hline TJA 46.3 & 46.3 & 5.7 & -1.4 & TJI 28.1 & 28.1 & 0.2 & -4.1 & TJD 1.0 & 70.7 & -5.2 & -2.2 \\
\hline TJA 51.0 & 51.0 & 5.6 & -4.6 & TJI 29.0 & 29.0 & 0.7 & -6.0 & TJD 1.1 & 70.8 & -5.1 & -2.4 \\
\hline TJB 0.0 & -1.8 & 4.0 & -4.3 & TJI 30.0 & 30.0 & 1.3 & -5.8 & TJD 1.6 & 71.3 & -3.4 & -1.9 \\
\hline TJB 0.25 & -1.6 & 4.1 & -4.1 & TJI 31.0 & 31.0 & 1.1 & -5.6 & TJIII 1.65 & 71.4 & -2.2 & -1.4 \\
\hline TJB 0.35 & -1.5 & 4.0 & -4.2 & TJII-20.0 & 32.2 & 3.2 & -6.1 & TJIII 1.7 & 71.4 & -1.7 & -1.4 \\
\hline TJB 0.8 & -1.0 & 3.9 & -3.5 & TJI 32.5 & 32.5 & 0.7 & -6.1 & TJIII 1.8 & 71.5 & -1.6 & -2.9 \\
\hline TJB 1.0 & -0.8 & 4.3 & -4.1 & TJII-19.0 & 33.2 & 1.8 & -5.7 & TJD 1.9 & 71.6 & -3.1 & -3.9 \\
\hline TJB 1.25 & -0.6 & 4.2 & -3.1 & TJI 34.0 & 34.0 & 1.3 & -4.3 & TJIII 1.9 & 71.6 & -1.3 & -4.5 \\
\hline TJB 1.5 & -0.3 & 4.0 & -3.6 & TJII-18.0 & 34.2 & 1.3 & -4.6 & TJIII 2.05 & 71.8 & -0.6 & -4.9 \\
\hline TJB 1.75 & -0.1 & 4.4 & -4.3 & TJI 35.0 & 35.0 & 1.1 & -4.2 & TJIII 2.1 & 71.8 & 0.1 & -4.5 \\
\hline TJI 0 & 0.0 & 4.3 & -3.8 & TJII-17.0 & 35.2 & 2.7 & -7.1 & TJIII 2.3 & 72.0 & 0.9 & -4.7 \\
\hline TJB 2.05 & 0.3 & 4.1 & -5.4 & TJII-16.0 & 36.2 & 1.5 & -6.8 & TJIII 2.5 & 72.2 & 0.7 & -4.0 \\
\hline TJB 2.4 & 0.6 & 3.9 & -5.2 & TJI 36.5 & 36.5 & 0.5 & -3.7 & TJIII 2.7 & 72.4 & 0.7 & -4.5 \\
\hline TJI 0.7 & 0.7 & 4.6 & -2.9 & TJII-15.0 & 37.2 & 0.1 & -4.1 & TJIII 2.85 & 72.6 & 1.1 & -3.5 \\
\hline TJB 2.8 & 1.0 & 3.9 & -4.6 & TJI 37.5 & 37.5 & 0.0 & -3.1 & TJIII 3.0 & 72.7 & 1.0 & -2.5 \\
\hline TJI 1.2 & 1.2 & 4.0 & -2.5 & TJII-14.0 & 38.2 & -1.7 & -5.4 & TJIII 3.2 & 72.9 & 1.6 & -3.7 \\
\hline TJI 1.8 & 1.8 & 4.2 & -2.9 & TJI 38.5 & 38.5 & -0.8 & -3.5 & TJIII 3.5 & 73.2 & 2.1 & -3.8 \\
\hline TJI 2.4 & 2.4 & 4.1 & -3.0 & TJII-13.0 & 39.2 & -0.8 & -3.1 & TJIII 3.7 & 73.4 & 2.3 & -3.2 \\
\hline TJI 3.0 & 3.0 & 4.0 & -3.6 & TJI 39.5 & 39.5 & -1.3 & -2.5 & TJIII 3.9 & 73.6 & 2.7 & -4.3 \\
\hline TJI 4.0 & 4.0 & 3.7 & -3.6 & TJC-12.0 & 40.2 & 0.1 & -4.8 & & & & \\
\hline TJI 5.0 & 5.0 & 3.5 & -3.6 & TJC-11.1 & 41.1 & 0.5 & -4.0 & & & & \\
\hline
\end{tabular}


Doushantuo Formation which are more easily traceable into shallow water facies sections, such as in the central Guizhou and northwestern Hubei provinces. However, the sequence boundary in the middle of the Doushantuo Formation is scarcely recognizable in sections of the Yangtze Gorges area, although it can be traced into northerly sections (Xiaofenghe and Zhangcunping sections) of the Huangling Anticline. Nevertheless, a surface of abrupt change in the stacking of parasequences in the middle of Member 2 at Wuhe (= Huajipo) and Jiulongwan sections ( $c a$ $59 \mathrm{~m}$ above the base of the Doushantuo Formation) may be equivalent to the middle Doushantuo sequence boundary (Fig. 5; fig. 16D-F in Zhu et al. 2007b). In the Tianjiayuanzi section, the middle sequence boundary is not visible because of poor outcrop exposure. Nonetheless, the highstand systems tract (HST) of Sequence 1 of the Doushantuo Formation is well developed in the lower part of Member 2, and characterized by a carbonate-rich interval with occasional oolites from $30-40 \mathrm{~m}$ above the base of the formation (Fig. 2C). Therefore, the sequence boundary at the top of Sequence 1 of the Doushantuo Formation is inferred to lie at a level $\mathrm{ca} 40 \mathrm{~m}$ above the base of the formation in the Tianjiayuanzi section. The carbonate-rich interval with oolites in the lower Member 2 of the Tianjiayuanzi section is similar to the Xiaofenghe section in northern Yichang, but does not occur in the other sections of the Yangtze Gorges area.

Sequence 2 of the Doushantuo Formation consists of the upper part of Member 2 and Member 3, and this is consistent throughout all sections of the Yangtze Gorges area. The black shale with intercalations of silty dolostone in the upper part of Member 2 represents a condensed sequence, whilst the dolostone with black cherty interlayers of Member 3 represents the highstand systems tract. A 0.9 m-thick contorted layer at the basal part of Member 3 in the Tianjiayuanzi section marks enhanced sediment transport rates during the early stages of regression. The late stages of regression are recorded by the deposits coarsening upward from grainstone to oolites, indicating very shallow depositional depths at the top of Sequence 2 in the Tianjiayuanzi section. It should be noted that there are three thick slumped beds in the upper part of Sequence 2 of the Doushantuo Formation in the Sixi section (Fig. 5), which is interpreted to represent an intra-shelf slope facies in the southwestern limb of the Huangling Anticline (Lu et al. 2009). Sliding can remove strata to the deeper portions of the basin, leading to erosional hiatuses or reduplication of the same succession. The sequence boundary at the top of Sequence 2 is marked by an erosional surface with irregular karstic infilling of ooids in the Tianjiayuanzi section (Fig. 3D). The sequence boundary is distinguishable in the well-known Jiulongwan section, where it is characterized by a thin shaly interval between the thick-bedded dolostone and finely laminated dolostone, corresponding to the rapid sea-level rise of Sequence 3 of the Doushantuo Formation.
Sequence 3 begins with a ca 3 m thick interval of laminated micritic dolostone in the Tianjiayuanzi section. The corresponding interval is variable in other sections of the Yangtze Gorges area. In the Jiulongwan section, the interval is of $\mathrm{ca} 30 \mathrm{~m}$ thick consisting of millimeter-scale alternating bands of limestone and dolostone (Fig. 5; Zhu et al. 2007b) but is absent in the Sixi section because of slumping (Fig. 5; Lu et al. 2009). The carbonate interval at the base of Sequence 3 represents a transgressive systems tract which is overlain by a condensed sequence of black shale marking the top of the Doushantuo Formation.

\section{Chemostratigraphy of the Doushantuo Formation in the Yangtze Gorges}

Previous chemostratigraphic studies indicate that there are three pronounced negative carbon isotope excursions within the Doushantuo Formation on the Yangtze Platform (Jiang et al. 2007, Zhou \& Xiao 2007, Zhu et al. 2007b). The first one (N1, CANCE in Zhu et al. 2007a) with $\delta^{13} \mathrm{C}$ values ranging from $-2 \%$ o to $-5 \%$ appears in the cap carbonate at the base of the Doushantuo Formation in every section of the central and southeastern Yangtze Platform. Unusually negative $\delta^{13} \mathrm{C}$ values with a nadir down to $-18 \%$ $-36 \%$ in the cap carbonates were detected in a few sections in the Yangtze Gorges area and its vicinity, and were considered to be evidence for gas hydrate destabilization during postglacial warming (Jiang et al. 2003a, Wang et al. 2008). Similarly negative $\delta^{13} \mathrm{C}$ values $(-11.6 \% \sim-18.7 \%$ ) are also recorded in the cap carbonate of the Tianjiayuanzi section (Fig. 4). However, these extremely negative $\delta^{13} \mathrm{C}$ values occur in the top part of the cap carbonate, casting doubt that the vein structures at the basal part of the cap carbonate may be related to methane seeps (Jiang et al. 2006, Zhou et al. 2010).

The second carbon isotope excursion (N2) occurs in the middle Doushantuo Formation. It should be pointed out that the stratigraphic horizon of N2 proposed by Zhu et al. (2007b) is not consistent with that in Jiang et al. (2007) and Zhou \& Xiao (2007), since Zhu et al.'s data are based on 12 sections throughout the Yangtze Platform, whereas the latter authors' data are based on sections in the Yangtze Gorges area mainly. According to Zhu et al.'s (2007b) data, the N2 (WANCE in Zhu et al. 2007a) appears near the sequence boundary at the middle of the Doushantuo Formation with $\delta^{13} \mathrm{C}$ values shifting from $+6 \%$ o to $-1 \%$. The WANCE is not seen in the Tianjiayuanzi section because of poor outcrop exposure. But it is well recorded in a drill core section in the Yangtze Gorges (Fig. 5; Sawaki et al. 2010). The position of the WANCE in the drill core is at approximately the same stratigraphic level as the $59 \mathrm{~m} \mathrm{level}$ in the Jiulongwan section, where a sequence boundary can 
Miao Lu et al. - Stratotype section of the Ediacaran Doushantuo Formation in South China

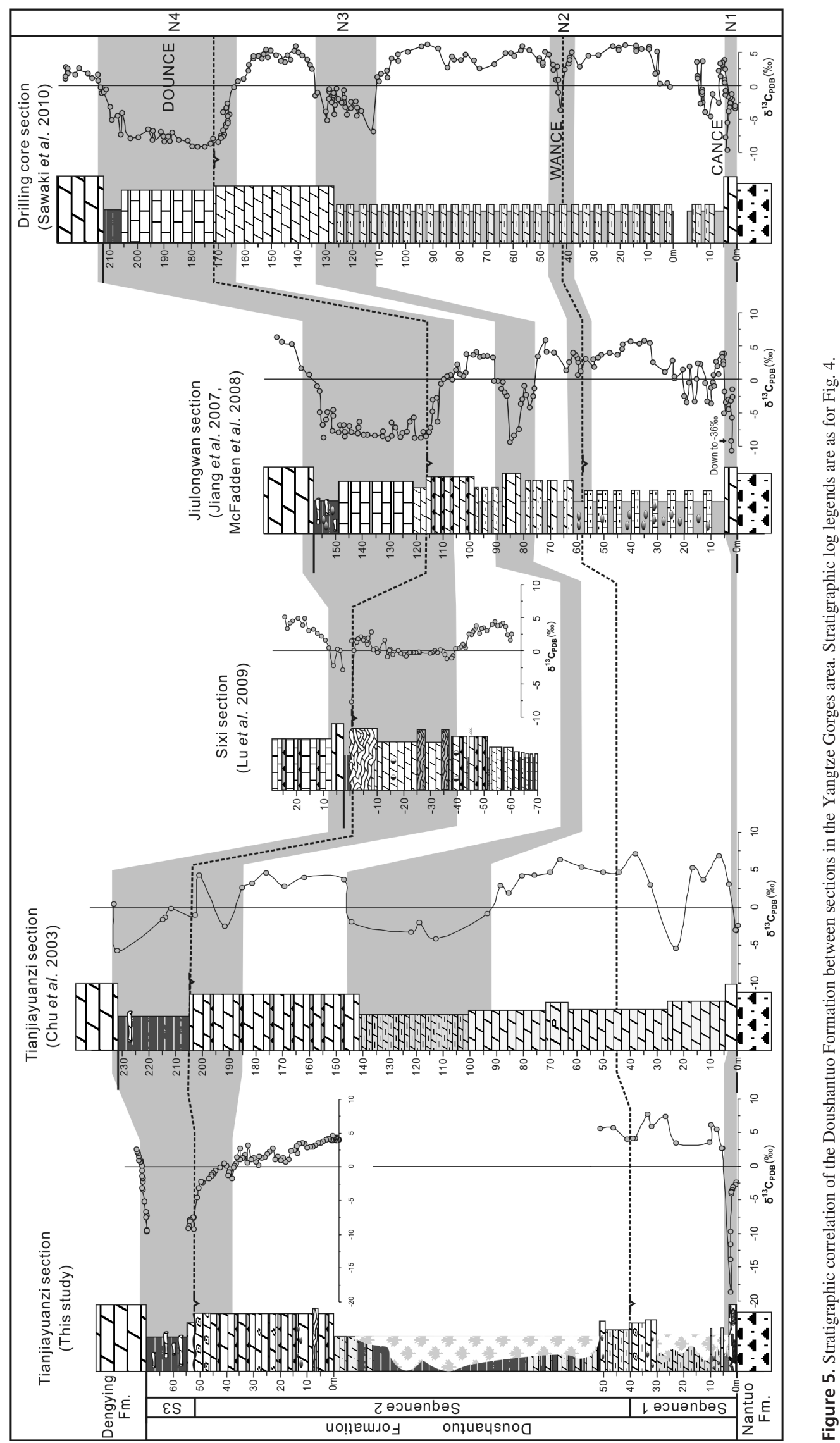


be extrapolated (see above) in the middle Doushantuo Formation (Fig. 5).

The N2 (or EN2) excursion proposed by Jiang et al. (2007) and Zhou \& Xiao (2007) occurs near the boundary between Member 2 and Member 3 (Fig. 5) and represents another carbon isotope excursion above the WANCE in the middle Doushantuo Formation. The excursion seems to be present in the Tianjiayuanzi section according to a previous study (Chu et al. 2003), but could not be confirmed by the present study because of poor exposure of the corresponding horizon. This excursion (N3 in Fig. 5) has yet to be documented in any section outside the Yangtze Gorges area. It thus certainly need to be established in future studies whether the excursion represents a local or a more widely distributed event.

The DOUNCE with $\delta^{13} \mathrm{C}$ values down to $-9 \%$ at the top of the Doushantuo Formation is regarded to coincide with the Shuram/Wonoka excursion which is documented in Ediacaran sequences all over the world, and thus represent a global event (Condon et al. 2005, Halverson et al. 2005, Kaufman et al. 2006, Zhu et al. 2007b, Melezhik et al. 2009, Le Guerroué \& Cozzi 2010, Swanson-Hysell et al. 2010). The DOUNCE is well recorded in the sections of the Yangtze Gorges area (Condon et al. 2005, Jiang et al. 2007, Zhu et al. 2007b, Sawaki et al. 2010). However, it shows dramatic variation between different sections as discussed in detail by Lu et al. (2009; Fig. 5). The DOUNCE in the Tianjiayuanzi section has not been documented by any previous studies possibly due to sporadic sampling without high-resolution stratigraphic control (Chu et al. 2003). Present data show that the DOUNCE is also recorded in the Tianjiayuanzi section and consists of three stages as shown in the Jiulongwan section. The excursion starts with steadily falling $\delta^{13} \mathrm{C}$ values across a ca $15 \mathrm{~m}$ thick carbonate interval with oolites, before $\delta^{13} \mathrm{C}$ values reach a nadir of $-9 \%$ in a $3 \mathrm{~m}$-thick unit of laminated dolostone above the second sequence boundary in the upper part of the Doushantuo Formation (Fig. 4). Although there are no available $\delta^{13} \mathrm{C}$ data from the black shale unit (Miaohe Member) at the top of the Doushantuo Formation, it can be inferred that the nadir of the $\delta^{13} \mathrm{C}$ values crosses the entire interval of the black shale because $\delta^{13} \mathrm{C}$ data exhibit steadily increasing values from $-9.5 \%$ o up to $+2.6 \%$ o within a $4 \mathrm{~m}$ interval at the base of the Dengying Formation (Fig. 4). This is the first time that it could be demonstrated that the nadir of the DOUNCE remains unchanged through the entire black shale unit of the Miaohe Member, and that $\delta^{13} \mathrm{C}$ values begin to recover at the base of the Dengying Formation which was dated at $551 \mathrm{Ma}$ (Condon et al. 2005). In comparison with the $\delta^{13} \mathrm{C}$ profile from the Jiulongwan outcrop and drill core sections in the Yangtze Gorges area, the interval of the $\delta^{13} \mathrm{C}$ nadir is much thinner in the Tianjiayuanzi section. The absence of such a nadir in the Sixi section can be attributed to slumping (Lu et al. 2009).

\section{Conclusions}

As shown in the Fig. 5, the Doushantuo Formation succession varies in thickness and lithofacies between different sections in the Yangtze Gorges area, suggesting considerable changes in sedimentary facies during the deposition of the Doushantuo Formation. Such lithological variation makes high-resolution stratigraphic correlation of the Doushantuo Formation between sections difficult not only within the Yangtze Gorges area but also in different areas of the Yangtze Platform. Such a correlation problem can be resolved through high-resolution carbon isotope chemostratigraphy and sequence stratigraphy with detailed sedimentary analysis. In comparison to previous studies of the Tianjiayuanzi section (Fig. 5; Chu et al. 2003), the present investigation provides a good example of the importance of high resolution sampling for chemostratigraphy as well as of the detailed lithofacies analysis for sequence stratigraphy.

Based on correlations of carbon isotope chemostratigraphy and sequence stratigraphy between the sections of the Yangtze Gorges area, we conclude that there are four negative carbon isotope excursions in the Doushantuo Formation in the Yangtze Gorges area (Fig. 5). The N1 (CANCE) occurs within the cap carbonate interval at the base of the formation, and extreme negative $\delta^{13} \mathrm{C}$ values are recorded in most of the sections in the Yangtze Gorges area. The N2 (WANCE) with $\delta^{13} \mathrm{C}$ values shifting from $+6 \%$ o to $-1 \%$ o appears in the middle of the Member 2 in a horizon equivalent to a major sequence boundary in the middle part of the formation. It is too difficult to interpret the extremely negative $\delta^{13} \mathrm{C}$ values of the $\mathrm{N} 3$ with a nadir down to $-9 \%$ (usually is $-2 \%$ $-5 \%$ ) which is reported by Jiang et al. (2007), because it has not yet been confirmed by data from other outcrop sections or even the well preserved drill-core section near Jiulongwan (Sawaki et al. 2010). To clarify this uncertainty, more high resolution $\delta^{13} \mathrm{C}$ data are needed in future from better outcrop sections. The N3 occurs in a horizon near the boundary between Member 2 and Member 3 of the formation, where $\delta^{13} \mathrm{C}$ values decrease to $-6 \%$. The N4 (DOUNCE) represents the most distinct negative carbon isotope excursion with a nadir of $\delta^{13} \mathrm{C}$ values down to $-9.6 \%$ at the top of the formation.

Sequence stratigraphy of the Tianjiayuanzi section confirms the presence of a sequence boundary with a karstic surface in the upper Doushantuo Formation, which coincides with a horizon where the nadir of $\delta^{13} \mathrm{C}$ of the DOUNCE begins. The base of the black shale member at the top of the Doushantuo Formation was considered to be a sequence boundary (Condon et al. 2005, Zhu et al. 2007b), but represents a flooding surface. The coincidence of the nadir of $\delta^{13} \mathrm{C}$ values within the DOUNCE starting at a sequence boundary is consistent with that shown by the Shuram excursion in Oman (Le Guerroué et al. 2006a, b), and provides further support to correlation of the DOUNCE with the Shuram 
excursion. Finally, the interval with the most negative $\delta^{13} \mathrm{C}$ values (nadir-9.5\%o) is shown to extend throughout the entire black shale member at the top of the Doushantuo Formation by new $\delta^{13} \mathrm{C}$ data from the base of the Dengying Formation.

\section{Acknowledgement}

This work is supported by the Chinese Academy of Sciences (KZCX-YW-Q08-4) and National Natural Science Foundation of China (40725005, 40930211, J0930006). We thank Chen Xiaoming (NIGPAS) for isotope analysis and Graham Shields for language improvement, and Tsuyoshi Komiya and another anonymous reviewer for improvement of the manuscript.

\section{Reference}

Bowring, S.A., Grotzinger, J.P., Condon, D.J., Ramezani, J., Newall, M.J. \& Allen, P.A. 2007. Geological constraints on the chronostratigraphic framework of the Huqf Supergroup, Sultanate of Oman. American Journal of Science 307(10), 1097-1145. DOI 10.2475/10.2007.01

Bristow, T.F., Kennedy, M.J., Derkowski, A., Droser, M.L., JIANG, G.Q. \& CREASER, R.A. 2009. Mineralogical constraints on the paleoenvironments of the Ediacaran Doushantuo Formation. Proceedings of the National Academy of Sciences of the United States of America 106(32), 13190-13195. DOI 10.1073/pnas.0901080106

Canfield, D.E., Poulton, S.W., Knoll, A.H., Narbonne, G.M., Ross, G., Goldberg, T. \& Strauss, H. 2008. Ferruginous conditions dominated later Neoproterozoic deep-water chemistry. Science 321(5891), 949-952. DOI 10.1126/science.1154499

Chen, J.Y., Oliveri, P., GaO, F., Dornbos, S.Q., Li, C.W., BotTJER, D.J. \& DAvidson, E.H. 2002. Precambrian animal life: Probable developmental and adult cnidarian forms from Southwest China. Developmental Biology 248(1), 182-196. DOI 10.1006/dbio.2002.0714

Chen, J.Y., BotTuer, D.J., Davidson, E.H., Li, G.X., GaO, F., Cameron, R.A., Hadfield, M.G., Xian, D., Tafforeau, P., JiA, Q., SugiYama, H. \& TAng, R. 2009. Phase contrast synchrotron X-ray microtomography of Ediacaran (Doushantuo) metazoan microfossils: Phylogenetic diversity and evolutionary implications. Precambrian Research 173(1-4), 191-200. DOI 10.1016/j.precamres.2009.04.004

Chen, X., Li, H., Chen, L., WANG, C. \& WANG, X.F. 2003. Carbon and oxygen isotope features of the Sinian carbonate strata in the Three Gorges region. Geological Review 49(1), 66-73.

Chu, X.L., Zhang, Q., Zhang, T. \& Feng, L. 2003. Sulfur and carbon isotopic variations in Neoproterozoic sedimentary rocks from southern China. Progress in Natural Science 13(11), 875-880. DOI 10.1080/10020070312331344580

Condon, D., Zhu, M.Y., Bowring, S., WAng, W., YAng, A.H. \& JIN, Y.G. 2005. U-Pb ages from the Neoproterozoic Doushantuo Formation, China. Science 308(5718), 95-98. DOI 10.1126/science.1107765

Derry, L.A., Kaufman, A.J. \& Jacobsen, S.B. 1992. Sedimentary cycling and environmental change in the Late Proterozoic - Evidence from stable and radiogenic isotopes. Geochimica et Cosmochimica Acta 56(3), 1317-1329.
Fike, D.A., Grotzinger, J.P., Pratt, L.M. \& Summons, R.E. 2006. Oxidation of the Ediacaran Ocean. Nature 444(7120), 744-747. DOI 10.1038/Nature05345

Gaidos, E.J., Dubuc, T., Dunford, M., McAndrew, P., PadillaGamiño, J., Studer, B., Weersingand, K. \& Stanley, S.M. 2007. The Precambrian emergence of animal life: a geobiological perspective. Geobiology 5(4), 351-373. DOI 10.1111/j.1472-4669.2007.00125.x

Grey, K. 2005. Ediacaran Palynology of Australia. Memoirs of the Association of Australasian Palaeontologists 31, 1-439.

Halverson, G.P., Hoffman, P.F., Schrag, D.P., Maloof, A.C. \& RiCE, A.H.N. 2005. Toward a Neoproterozoic composite carbon-isotope record. Geological Society of America Bulletin 117(9-10), 1181-1207. DOI 10.1130/B25630.1

Halverson, G.P., Wade, B.P., Hurtgen, M.T. \& Barovich, K.M. 2010. Neoproterozoic chemostratigraphy. Precambrian Research 182(4), 337-350.

DOI 10.1016/j.precamres.2010.04.007.

Jiang, G.Q., Kennedy, M.J. \& Christie-Blick, N. 2003a. Stable isotopic evidence for methane seeps in Neoproterozoic postglacial cap carbonates. Nature 426(6968), 822-826. DOI 10.1038/Nature02201

Jiang, G.Q., Sohl, L.E. \& Christie-Blick, N. 2003b. Neoproterozoic stratigraphic comparison of the Lesser Himalaya (India) and Yangtze Block (South China): Paleogeographic implications. Geology 31(10), 917-920.

DOI $10.1130 / \mathrm{g} 19790.1$

Jiang, G.Q., Kaufman, A.J., Christie-Blick, N., Zhang, S.H. \& Wu, H. 2007. Carbon isotope variability across the Ediacaran Yangtze platform in South China: Implications for a large surface-to-deep ocean $\delta^{13} \mathrm{C}$ gradient. Earth and Planetary Science Letters 261(1-2), 303-320. DOI 10.1016/j.epsl.2007.07.009

Jiang, G.Q., Kennedy, M.J., Christie-Blick, N., Wu, H. \& ZHANG, S.H. 2006. Stratigraphy, sedimentary structures, and textures of the late Neoproterozoic Doushantuo cap carbonate in south China. Journal of Sedimentary Research 76(7-8), 978-995. DOI 10.2110/Jsr.2006.086

JiAng, G.Q., Shi, X.Y., Zhang, S.H., Wang, Y. \& XiaO, S.H. 2011. Stratigraphy and paleogeography of the Ediacaran Doushantuo Formation (ca. 635-551 Ma) in South China. Gondwana Research 19(4), 831-849. DOI 10.1016/j.gr.2011.01.006

Kaufman, A.J., Jiang, G.Q., Christie-Blick, N., BanerJee, D.M. \& RAI, V. 2006. Stable isotope record of the terminal Neoproterozoic Krol platform in the Lesser Himalayas of northern India. Precambrian Research 147(1-2), 156-185. DOI 10.1016/j.precamres.2006.02.007

KaufMan, A.J. \& KNOLL, A.H. 1995. Neoproterozoic variations in the C-isotopic composition of seawater: stratigraphic and biogeochemical implications. Precambrian Research 73(1-4), 27-49. DOI 10.1016/0301-9268(94)00070-8

Knoll, A.H., Walter, M.R., Narbonne, G.M. \& ChristieBLICK, N. 2004. A new period for the Geologic Time Scale. Science 305(5684), 621-622. DOI 10.1126/science.1098803

LAmbert, I.B., Walter, M.R., ZANG, W.L., Lu, S.N. \& MA, G.G. 1987. Palaeoenvironment and carbon isotope stratigraphy of Upper Proterozoic carbonates of the Yangtze Platform. Nature 325(6100), 140-142. DOI 10.1038/325140a0

Le Guerroué, E., Allen, P.A. \& Cozzi, A. 2006a. Chemostratigraphic and sedimentological framework of the largest negative carbon isotopic excursion in Earth history: the Neo- 
proterozoic Shuram Formation (Nafun Group, Oman). Precambrian Research 146(1-2), 68-92.

DOI 10.1016/j.precamres.2006.01.007

Le Guerroué, E., Allen, P.A., Cozzi, A., Etienne, J.L. \& FANNING, C.M. 2006b. 50 Myr recovery from the largest negative $\delta^{13} \mathrm{C}$ excursion in the Ediacaran ocean. Terra Nova 18(2), 147-153. DOI 10.1111/j.1365-3121.2006.00674.x

Le Guerroué, E. \& CozzI, A. 2010. Veracity of Neoproterozoic negative C-isotope values: The termination of the Shuram negative excursion. Gondwana Research 17(4), 653-661. DOI 10.1016/j.gr.2009.11.002

Li, C.W., Love, G.D., Lyons, T.W., Fike, D.A., Sessions, A.L. \& Chu, X.L. 2010. A Stratified Redox Model for the Ediacaran Ocean. Science 328(5974), 80-83.

DOI 10.1126/science.1182369

Lu, M., Zнu, M.Y. \& Zнао, M. 2009. Litho- and carbon isotope stratigraphy of the Ediacaran system in the Sixi section (Yangtze Gorges), Yichang, Hubei. Journal of Stratigraphy 33(4), 359-372.

McFadden, K.A., Huang, J., Chu, X.L., Jiang, G.Q., Kaufman, A.J., Zhou, C.M., Yuan, X.L. \& XiaO, S.H. 2008. Pulsed oxidation and bioloical evolution in the Ediacaran Doushantuo Formation. Proceedings of the National Academy of Sciences of the United States of America 105(9), 3197-3202. DOI 10.1073/pnas.0708336105

McFadden, K.A., Xiao, S.H., Zhou, C.M. \& Kowalewski, M. 2009. Quantitative evaluation of the biostratigraphic distribution of acanthomorphic acritarchs in the Ediacaran Doushantuo Formation in the Yangtze Gorges area, South China. Precambrian Research 173(1-4), 170-190. DOI 10.1016/j.precamres.2009.03.009

Melezhik, V.A., Pokrovsky, B.G., FAllick, A.E., Kuznetsov, A.B. \& Bujakaite, M.I. 2009. Constraints on ${ }^{87} \mathrm{Sr} /{ }^{86} \mathrm{Sr}$ of Late Ediacaran seawater: insight from Siberian high-Sr limestones. Journal of the Geological Society, London 166(1), 183-191. DOI 10.1144/0016-76492007-171

Sawaki, Y., Ohno, T., Tahata, M., Komiya, T., Hirata, T., Maruyama, S., Windley, B.F., Han, J., Shu, D. \& Li, Y. 2010. The Ediacaran radiogenic $\mathrm{Sr}$ isotope excursion in the Doushantuo Formation in the Three Gorges area, South China. Precambrian Research 176(1-4), 46-64. DOI 10.1016/j.precamres.2009.10.006

Squire, R.J., CAmpBell, I.H., Allen, C.M. \& Wilson, C.J.L. 2006. Did the Transgondwanan Supermountain trigger the explosive radiation of animals on Earth? Earth and Planetary Science Letters 250(1-2), 116-133. DOI 10.1016/j.epsl.2006.07.032

Swanson-Hysell, N.L., Rose, C.V., Calmet, C.C., Halverson, G.P., Hurtgen, M.T. \& Maloof, A.C. 2010. Cryogenian glaciation and the onset of carbon-isotope decoupling. Science 328(5978), 608-611. DOI 10.1126/science.1184508

Van Wagoner, J.C., Mitchum, R.M., CAmpion, K.M. \& RAHMANIAN, V.D. 1990. Siliciclastic sequence stratigraphy in well logs, cores, and outcrops. 55 pp. American Association of Petroleum Geologists, Tulsa, OK (USA).

WAnG, J.S., JiAnG, G.Q., XIAO, S.H., LI, Q. \& WeI, Q. 2008. Carbon isotope evidence for widespread methane seeps in the ca. $635 \mathrm{Ma}$ Doushantuo cap carbonate in south China. Geology 36(5), 347-350. DOI 10.1130/G24513a.1

Wang, W., Matsumoto, R., Wang, H., Ohde, S., Kano, A. \& Mu, X. 2002a. Isotopic chemostratigraphy of the upper Sinian in Three Gorges area. Acta Micropalaeontologica Sinica 19(4), 382-388.
WANG, X.F., Chen, X., WANG, C. \& ChEn, L. 2001a. Basal boundary and its inner chronostratigraphic subdivision of the Sinian System in China. Journal of Stratigraphy 25 (Supplement), 370-376.

Wang, X.F., Erdtmann, B.-D., Chen, X. \& MaO, X. 1998. Integrated sequence-, bio- and chemostratigraphy of the terminal Proterozoic to Lowermost Cambrian "black rock series" from central South China. Episodes 21(3), 178-189.

WANG, Z.H., GAO, L. \& YIN, C. 2001b. Ascertainment and stratigraphic division of the Sinian stratotype section. Geological Review 47, 449-456. DOI CNKI:SUN:DZLP.0.2001-05-000

WANG, Z.H., YANG, J.D. \& Sun, W.G. 1996. Carbon isotope record of Sinian seawater in Yangtze Platform. Geological Journal of Universities 2(1), 112-120.

WANG, Z.H., Yin, C., GAO, L. \& LiU, Y. 2002b. Chemostratigraphic characteristics and correlation of the Sinian stratotype in the eastern Yangtze Gorges area, Yichang, Hubei Province. Geological Review 48(4), 408-415.

Xiao, S.H., Knoll, A.H., Yuan, X.L. \& Pueschel, C.M. 2004. Phosphatized multicellular algae in the Neoproterozoic Doushantuo Formation, China, and the early evolution of florideophyte red algae. American Journal of Botany 91(2), 214-227. DOI 10.3732/ajb.91.2.214

XiaO, S.H., Zhang, Y. \& Knoll, A.H. 1998. Three-dimensional preservation of algae and animal embryos in a Neoproterozoic phosphorite. Nature 391(6667), 553-558. DOI $10.1038 / 35318$

YAnG, J.D., Sun, W.G., WANG, Z.Z., Xue, Y.S. \& TAO, X.C. 1999. Variations in $\mathrm{Sr}$ and $\mathrm{C}$ isotopes and $\mathrm{Ce}$ anomalies in successions from China: evidence for the oxygenation of Neoproterozoic seawater? Precambrian Research 93(2-3), 215-233. DOI 10.1016/S0301-9268(98)00092-8

Yin, L.M., Zhu, M.Y., Knoll, A.H., Yuan, X.L., Zhang, J.M. \& Hu, J. 2007. Doushantuo embryos preserved inside diapause egg cysts. Nature 446(7136), 661-663. DOI 10.1038/Nature05682

ZhaO, Z.Q., XING, Y., MA, G. \& ChEN, Y. 1985. Biostratigraphy of the Yangtze Gorges area: (1) Sinian. 143 pp. Geological Publishing House, Beijing. [in Chinese with English summary]

Zhou, C.M. \& XIAO, S.H. 2007. Ediacaran $\delta^{13} \mathrm{C}$ chemostratigraphy of South China. Chemical Geology 237(1-2), 89-108. DOI 10.1016/j.chemgeo.2006.06.021

Zhou, C.M., Bao, H.M., Peng, Y.B. \& Yuan, X.L. 2010. Timing the deposition of ${ }^{17} \mathrm{O}$-depleted barite at the aftermath of Nantuo glacial meltdown in South China. Geology 38(10), 903-906. DOI 10.1130/G31224.1

Zhu, M.Y., Zhang, J.M., Steiner, M., Yang, A.H., Li, G.X. \& ERDTMANN, B.-D. 2003. Sinian-Cambrian stratigraphic framework for shallow- to deep-water environments of the Yangtze Platform: an integrated approach. Progress in Nature Science 13(12), 951-960. DOI 10.1080/10020070312331344710

Zhu, M.Y., Strauss, H. \& Shields, G.A. 2007a. From snowball earth to the Cambrian bioradiation: Calibration of EdiacaranCambrian earth history in South China. Palaeogeography, Palaeoclimatology, Palaeoecology 254(1-2), 1-6. DOI 10.1016/j.palaco.2007.03.026

Zhu, M.Y., Zhang, J.M. \& YANG, A.H. 2007b. Integrated Ediacaran (Sinian) chronostratigraphy of South China. Palaeogeography, Palaeoclimatology, Palaeoecology 254(1-2), 7-61. DOI 10.1016/j.palaeo.2007.03.025

Zhu, M.Y., Gehling, J., XiaO, S.H., Zhao, Y.L. \& Droser, M.L. 2008. Eight-armed Ediacara fossil preserved in contrasting taphonomic windows from China and Australia. Geology 36(11), 867-870. DOI 10.1130/G25203a.1 